\title{
PENGARUH TOPOGRAFI LAHAN TERHADAP PRODUKTIVITAS KELAPA SAWIT (Elaeis guineensis Jacq.) DI PT. DHARMA INTISAWIT NUGRAHA MUARA WAHAU KABUPATEN KUTAI TIMUR
}

\section{THE EFFECT OF LAND TOPOGRAPHY ON OIL PALM PRODUCTIVITY (Elaeis guineensis Jacq.) IN PT. DHARMA INTISAWIT NUGRAHA MUARA WAHAU KUTAI TIMUR DISTRICT}

\author{
Humairo Aziza ${ }^{1 \star}$, Sri Ngapiyatun ${ }^{1}$, Muhammad Arifin ${ }^{1}$, Wartomo $^{1}$, Rusli Anwar ${ }^{1}$ \\ ${ }^{1}$ Politeknik Pertanian Negeri Samarinda, Kampus Gunung Panjang, Jl. Samratulangi, \\ Samarinda, Indonesia \\ *elo.pascaunmul@gmail.com
}

\begin{abstract}
Oil palm is one of the potential commodities whose cultivation trend began in 2003 in East Kalimantan which has the characteristics of hilly land. Oil palm itself is preferable to grow at an altitude of $400 \mathrm{~m}$ asl with a slope of up to $23 \%$ or at $12^{\circ}$. Therefore, this research is motivated to determine the yield of oil palm plantations in certain land slope classifications. The study was conducted on 2 afdeling which have different land classifications with an area of \pm 14,000 ha. Then for comparison, it was taken through production data in 2019 with 2 treatments and 12 replications, which were processed using Analysis Of Variance (ANOVA) Two Way Anova. Primary data were obtained through field observations, as well as soil sampling, which were analyzed directly for soil physical properties and laboratory for chemical properties including $\mathrm{pH} \mathrm{H}_{2} \mathrm{O}$, Nitrogen (N), Phosphorus (P), Potassium (K) and Magnesium (Mg.). The results of the research on the effect of slope on oil palm production by various methods indicate that the land slope factor does not have a significant effect on oil palm productivity.
\end{abstract}

Keywords : land classification, oil palm, productivity

\section{PENDAHULUAN}

Pengembangan perkebunan kelapa sawit di Indonesia dimulai sejak tahun 1970 dan mengalami perkembangan pertumbuhan yang cukup cepat terutama periode tahun 1980-an. Pada tahun 1980 areal kelapa sawit hanya seluas 294.000 hektar dan terus meningkat dengan pesat sehingga pada tahun 2009 mencapai 7,32 juta hektar, dengan rincian $47,81 \%$ berupa Perkebunan Besar Swasta (PBS), 43,76\% Perkebunan Rakyat (PR), dan $8,43 \%$ Perkebunan Besar Negara (PBN). Dengan luas areal yang ada, Indonesia merupakan negara produsen minyak sawit terbesar di dunia.
Pada tahun 2009, produksi minyak sawit Indonesia mencapai 20,6 juta ton, diikuti oleh Malaysia pada urutan kedua dengan produksi 17,57 juta ton. Pada tahun 2014, menurut data Kementerian Pertanian, jumlah total produksi minyak kelapa sawit Indonesia mencapai 31,5 juta dengan 21,5 juta ton di ekspor ke luar negeri. Sebagian besar hasil produksi minyak sawit di Indonesia merupakan komoditi ekspor. Pangsa ekspor kelapa sawit hingga tahun 2014 mencapai $80 \%$ dari total produksi.

Kalimantan Timur dengan luas wilayah daratan hampir 20 juta hektar memiliki lahan yang potensial untuk dijadikan perkebunan kelapa sawit mencapai 4,7 juta hektar, merupakan 
terbesar kedua setelah Papua. Pemerintah daerah telah menetapkan kelapa sawit sebagai salah satu komoditi unggulan perkebunan Kalimantan Timur dimana program 1 juta hektar kelapa sawit telah dicanangkan selama 15 tahun mulai tahun 2003 hingga 2018 dengan realisasi lahan sampai dengan tahun 2007 seluas 293.953 hektar. Sehingga berdasarkan sisa waktu dan luasan yang harus dicapai diperlukan percepatan sekitar rata-rata 59.258 hektar setiap tahun.

Di daerah tropis secara umum dicirikan oleh keadaan iklim yang hampir seragam. Namun dengan adanya perbedaan geografis seperti perbedaan ketinggian tempat di atas permukaan laut (dpl) akan menimbulkan perbedaan cuaca dan iklim secara keseluruhan pada tempat tersebut, terutama suhu, kelembaban dan curah hujan. Unsurunsur cuaca dan iklim tersebut banyak dikendalikan oleh letak lintang, ketinggian, jarak dari laut, topografi, jenis tanah dan vegetasi. Pada dataran rendah ditandai oleh suhu lingkungan, tekanan udara dan oksigen yang tinggi. Sedangkan dataran tinggi banyak mempengaruhi penurunan tekanan udara dan suhu udara serta peningkatan curah hujan. Laju penurunan suhu akibat ketinggian memiliki variasi yang berbeda-beda untuk setiap tempat (Sangadji, 2001).

Rata-rata penurunan suhu udara di Indonesia sekitar $0,5-0,6^{\circ} \mathrm{C}$ tiap kenaikan 100 meter (Handoko, 1995). Kemiringan lereng merupakan faktor yang perlu diperhatikan, sejak dari penyiapan lahan pertanian, usaha penanamannya, pengambilan produkproduk serta pengawetan lahan. Lahan yang mempunyai kemiringan dapat lebih mudah terganggu atau rusak, lebih-lebih bila derajat kemiringannya besar. Tanah yang mempunyai kemiringan $>15 \%$ dengan curah hujan yang tinggi dapat mengakibatkan longsor tanah (Kartasapoetra,1990). Lereng yang semakin curam dan semakin panjang akan meningkatkan kecepatan aliran permukaan dan volume air permukaan semakin besar, sehingga benda yang bisa diangkut akan lebih banyak (Martono, 2004). Salah satu upaya untuk mengurangi tingkat bahaya erosi pada kemiringan lahan dengan cara pembuatan teras (Kartasapoetra \& Sutedjo, 1987).

Provinsi ini mempunyai topografi bergelombang dari kemiringan landai sampai curam, dengan ketinggian berkisar antara 0-1500 meter di atas permukaan laut dengan kemiringan antara $0-60$ persen. Daerah dataran rendah pada umunya dijumpai pada kawasan sepanjang sungai. Sedangkan daerah perbukitan dan pegunungan memiliki ketinggian rata-rata lebih dari $1000 \mathrm{~m}$ dpl dengan kemiringan 30 persen (Anonim, 2014).

Kondisi topografi tersebut sangat berpengaruh terhadap peluang budidaya suatu jenis komoditi, potensi dan persediaan air, dinamika hidrologi dan kerentanan terhadap erosi. Dilihat dari topografi, sebagian besar atau 43,35 persen wilayah daratan termasuk dalam kemiringan diatas 40 persen dan 43,22 persen terletak pada ketinggian 100$1000 \mathrm{~m}$ dpl, sehingga pemanfaatan lahan di Provinsi Kalimantan Timur harus memperhatikan karakteristik lahan tersebut.

Berdasarkan uraian di atas maka rumusan permasalahannya yaitu: apakah ada pengaruh karakteristik lahan terhadap perbedaan hasil berat maupun jumlah pada produksi kelapa sawit, apakah ada pengaruh karakteristik lahan terhadap hasil produktivitas kelapa sawit dan bagaimana tingkat keeratan antara produktivitas dan karakteristik lahan.

Penelitian ini hanya terfokus pada pengaruh tingkat karakteristik lahan tertentu terhadap produktivitas kelapa sawit serta pengaruh karakteristik terhadap kesuburan lahan dengan kedalaman 0-60 cm. 
Tujuan penelitian ini adalah untuk mengetahui pengaruh karakteristik lahan terhadap perbedaan hasil berat maupun jumlah pada produksi kelapa sawit, mengetahui pengaruh karakteristik lahan terhadap hasil produktivitas kelapa sawit dan menganalisa hubungan tingkat keeratan antara produktivitas dan karakteristik lahan.

\section{METODOLOGI}

\section{Tempat dan Waktu Penelitian}

Pelaksanaan penelitian dilakukan di lahan perkebunan milik perusahaan PT. Dharma Intisawit Nugraha Long Kejiak II Estate Kecamatan Muara Wahau Kabupaten Kutai Timur. Jangka waktu yang dibutuhkan dari seluruh pelaksanaan penelitian mulai dari persiapan hingga pembuatan laporan \pm 10-12 bulan. Proses pelaksanaan penelitian mulai dari tahap persiapan dimulai pada tanggal 1 April 2019.

\section{Alat dan Bahan}

Alat yang digunakan dalam penelitiaan adalah klinometer, roll meter, soil sampler, kayu penumbuk, plastik sampel, kamera dokumentasi, dan ATK. Sedangkan bahan yang digunakan adalah sampel tanah, dan sampel kelapa sawit.

\section{Metode Pengambilan Data}

1. Studi Literatur

Mencari referensi teori yang relevan dengan kasus atau permasalahan yang ditemukan. Data sekunder dikumpulkan dengan metode penelusuran literatur dan data lain yang dibutuhkan.

2. Survei Lapangan

Survei lapangan dilakukan untuk mendapatkan data primer seperti karakteristik kesuburan tanah, tingkat kelerengan dan perlakuan konservasi yang dilakukan perusahaan. Pengambilan sampling dilakukan pada 2 afdeling dan tingkat kemiringan bervariasi.

3. Observasi

Observasi adalah metode pengumpulan data melalui pengamatan langsung atau peninjauan secara cermat dan langsung di lapangan atau lokasi penelitian. Dalam hal ini, peneliti dengan berpedoman kepada desain penelitiannya perlu mengunjungi lokasi penelitian untuk mengamati langsung berbagai hal atau kondisi yang ada di lapangan.

4. Analisis Peta

Peta lokasi diperlukan guna menunjukan posisi dan lokasi penelitian serta untuk mengetahui karakteristik lahan yang ada pada perusahaan.

5. Analisis Sampling

Sampel tanah yang dianalisis di laboratorium meliputi unsur kimia tanah yang selanjutnya diinterpretasi menjadi karakteristik kesuburan tanah.

\section{Prosedur Penelitian}

1. Persiapan

Ada beberapa tahapan persiapan sebelum melakukan penelitian antara lain:

a. Persiapan administrasi

Pengurusan surat perihal perijinan melakukan penelitian di suatu tempat/perusahaan.

b. Persiapan mekanisme

Persiapan mekanisme adalah persiapan berupa alat dan bahan yang dibutuhkan selama melaksanakan penelitian, agar proses pengambilan data dapat berjalan dengan baik.

c. Persiapan lapangan

1) Menentukan plot penelitian berdasarkan informasi lokasi yang sesuai dengan karakteristik pengamatan pada perusahaan dengan 
melihat peta lokasi yang dimiliki perusahaan.

2) Menentukan 2 lokasi yang memiliki klasifikasi karakteristik lahan tertentu.

3) Melakukan observasi pada lokasi yang telah ditentukan.

d. Plot penelitian

Penentuan plot penelitian diambil pada 2 afdeling dengan klasifikasi lahan datar dan berbukit.

e. Penentuan sampel

Sampel diambil dari data ratarata produksi ton/ha dan janjang/pokok pada 2 afdeling tahun 2019.

f. Pengambilan data

1) Menghitung berat tandan rata-rata ton/ha.

2) Menghitung jumlah tandan rata-rata janjang/pokok.

3) Mengambil data faktor yang mempengaruhi produktivitas kelapa sawit sebagai pendukung penelitian yang meliputi:

a) Sampel tanah pada setiap plot penelitian dengan kedalaman 0- 60 $\mathrm{cm}$, dengan menganalisa unsur hara makro $\mathrm{pH} \mathrm{H}_{2} \mathrm{O}$, Nitrogen, Phosfor, Kalium dan Magnesium sebagai indikator kesuburan tanah.

b) Mengamati perlakuan pemberian pupuk kimia

c) Mengamati perlakuan land application.

d) Mengamati intensitas curah hujan.

e) Mengamati vegetasi yang ada pada plot penelitian.

f) Mengamati tindakan konservasi di sekitar plot penelitian.

g) Mengamati potensial genetis.
2. Perlakuan

Penelitian ini terdiri dari 2 perlakuan yaitu:

a. Perlakuan yang diberikan terhadap klasifikasi lahan datar.

b. Perlakuan yang diberikan terhadap klasifikasi lahan perbukitan.

3. Rancangan

Pola penelitian yang digunakan adalah percobaan rancangan acak lengkap kepada 2 perlakuan yang telah disebutkan. Ulangan yang digunakan adalah data rata-rata produksi ton/ha dan janjang/pokok selama 12 bulan yang ada pada perusahaan.

\section{Analisis data}

Data yang diperoleh merupakan data primer dan sekunder yang didapat secara langsung baik melalui pengamatan secara langsung, di lapangan maupun di laboratorium. Data yang diperoleh selanjutnya dianalisis secara deskriptif dan kuantitatif dengan perhitungan rataan dan perhitungan matematika sederhana lainnya. Selanjutnya, dilakukan analisis data menggunakan pendekatan rancangan acak lengkap dengan metode Two Way Annova dan berbagai tahapannya dengan rumus sebagai berikut :

\section{Model Linear RAL Faktoral}

$$
Y i j k=\mu+\alpha i+\beta j+(\alpha \beta) i j+\varepsilon i j k
$$

Keterangan :

Yijk $=$ Hasil pengamatan untuk faktor A ke-i, faktor B ke-j, pada

$$
\begin{array}{ll} 
& \text { ulangan ke-k } \\
\mu & =\text { Rataan umum } \\
\alpha \mathrm{i} & =\text { Pengaruh faktor A ke-i } \\
\beta \mathrm{j} & =\text { Pengaruh faktor B ke-j } \\
(\alpha \beta) \mathrm{ij} & =\text { Interaksi antara A dan } \\
\mathrm{B} \text { pada faktor A ke-i, faktor B ke-j }
\end{array}
$$


eijk = Galat percobaan untuk faktor A level ke-i, faktor B level ke-j pada ulangan/

2. Hipotesis

$$
\text { kelompok ke-k }
$$

a. Uji Normalitas

1) Apabila Sig Hitung < Sig t.s $5 \%=0,05$, maka nilai residual standar berdistribusi normal.

2) Apabila Sig Hitung > Sig t.s $5 \%=0,05$, maka nilai residual standar tidak berdistribusi normal.

b. Uji Homogenitas

1) Apabila Sig Hitung < Sig t.s $5 \%=0,05$, maka varian dikatakan homogen atau sama atau sejenis.

2) Apabila Sig Hitung > Sig t.s $5 \%=0,05$, maka varian dikatakan tidak homogen atau tidak sama atau tidak sejenis.

c. Uji Two Way Anova

1) Apabila Sig Hitung < Sig t.s $5 \%=0,05$, maka rata-rata tidak ada pengaruh yang signifikan.

2) Apabila Sig Hitung > Sig t.s $5 \%=0,05$, maka rata-rata ada pengaruh yang signifikan.

Selain analisis data penelitian, dilakukan analisis kesuburan tanah seperti : a. Keadaan fisika tanah meliputi kelerengan serta perlakuan konservasi terasering.

b. Keadaan kimia tanah meliputi unsur hara makro $\mathrm{pH} \mathrm{H}_{2} \mathrm{O}$, Nitrogen, Phosfor, Kalium dan Magnesium.

\section{HASIL DAN PEMBAHASAN}

\section{Hasil}

Berdasarkan hasil penelitian yang telah dilakukan di PT. Dharma Intisawit Nugraha Long Kejiak II Estate Kecamatan Muara Wahau Kabupaten Kutai Timur yang menunjukan bahwa :

1. Topografi Lahan

Lahan yang ada pada plot penelitian merupakan lahan dataran dengan persentase sekitar $95 \%$ dari keseluruhan luasan yang ada pada lokasi dengan tingkat kemiringan $<10^{\circ}$ yang selanjutnya disebut sebagai perlakuan $\mathrm{P} 1$, sedangkan untuk lahan perbukitan dengan persentase sekitar 90\% dari keseluruhan luasan yang ada pada lokasi dengan tingkat kelerengan lahan $>20^{\circ}$ yang selanjutnya disebut dengan perlakuan P2.

2. Hasil Produksi

Hasil rekapitulasi data produksi kelapa sawit yang ada pada perusahaan selama 1 tahun dapat dilihat pada tabel berikut :

Tabel 1. Hasil rekapitulasi data rata-rata produksi tahun 2019

\begin{tabular}{lcccc}
\hline \multirow{2}{*}{ Ulangan } & \multicolumn{2}{c}{$\mathrm{P} 1$} & \multicolumn{2}{c}{ P2 } \\
\cline { 2 - 5 } & Ton/Ha & Jjg/Pkk & Ton/Ha & Jjg/Pkk \\
\hline Januari & 2.74 & 1.44 & 2.91 & 1.39 \\
Februari & 2.08 & 1.12 & 2.94 & 1.45 \\
Maret & 2.71 & 1.26 & 2.13 & 1.05 \\
April & 2.57 & 1.15 & 2.84 & 1.38 \\
Mei & 2.78 & 1.13 & 2.73 & 1.18 \\
Juni & 2.21 & 0.90 & 2.51 & 1.12 \\
Juli & 1.70 & 0.70 & 1.82 & 0.87 \\
Agustus & 2.73 & 1.03 & 3.61 & 1.51 \\
\hline
\end{tabular}




\begin{tabular}{ccccc}
\hline \multirow{2}{*}{ Ulangan } & \multicolumn{2}{c}{$\mathrm{P} 1$} & \multicolumn{2}{c}{$\mathrm{P} 2$} \\
\cline { 2 - 5 } & Ton/Ha & Jjg/Pkk & Ton/Ha & Jjg/Pkk \\
\hline September & 2.96 & 1.22 & 2.25 & 1.08 \\
Oktober & 3.66 & 1.61 & 2.75 & 1.36 \\
November & 3.35 & 1.37 & 2.89 & 1.31 \\
Desember & 3.38 & 1.85 & 3.02 & 1.78 \\
\hline Total & 32.88 & 14.78 & 32.40 & 15.48 \\
\hline Rata-rata & 2.74 & 1.23 & 2.70 & 1.29 \\
\hline
\end{tabular}

Keterangan :

Perlakuan $\mathrm{P}_{1}=$ klasifikasi lahan datar

Perlakuan $\mathrm{P}_{2}=$ klasifikasi lahan perbukitan

Berdasarkan tabel di atas dapat dilihat bahwa hasil produksi pada perlakuan P1 memiliki jumlah produksi tonase per hektar lebih tinggi dibandingkan dengan perlakuan P2, namun untuk produksi jumlah janjang per pokok terlihat lebih kecil dibandingkan dengan perlakuan P2.
3. Pengolahan Data

Untuk mengetahui lebih lanjut pengaruh antara perlakuan $\mathrm{P} 1$ dengan P2 maka dilakukan uji Analysis Of Variance (ANOVA). Namun sebelumnya harus melakukan uji normalitas nilai residual standar seperti pada tabel 2 berikut :

Tabel 2. Uji Normalitas nilai residual standar

\begin{tabular}{cccccccc}
\hline & \multicolumn{3}{c}{ Kolmogorov-Smirnov $^{\mathrm{a}}$} & \multicolumn{3}{c}{ Shapiro-Wilk } \\
\cline { 2 - 7 } & Statistic & $\mathrm{df}$ & Sig. & $\begin{array}{c}\text { Stat } \\
\text { istic }\end{array}$ & df & Sig. \\
\hline $\begin{array}{c}\text { Standardized } \\
\begin{array}{c}\text { Residual for } \\
\text { Hasil }\end{array}\end{array}$ & 0.109 & 48 & $0.200^{*}$ & $\begin{array}{c}0.9 \\
75\end{array}$ & 48 & 0.395 \\
\hline
\end{tabular}

Dalam tabel uji normalitas di atas, dapat dilihat pada nilai signifikan (Sig) yang menunjukan 0.395 lebih besar dari 0.05 maka nilai residual standard berdistribusi normal oleh karena itu uji normalitas telah terpenuhi. Dengan demikian syarat pertama untuk melakukan uji Two Way Anova dapat dilanjutkan seperti pada tabel berikut :

Tabel 3. Data Variabel penelitian

\begin{tabular}{lccc}
\hline Hasil & Kode & Value Label & N \\
\hline Data Produksi & 1 & Ton/Ha & 24 \\
Karakteristik Lahan & 2 & Jjg/Pkk & 24 \\
& 1 & Dataran & 24 \\
& 2 & Perbukitan & 24 \\
\hline
\end{tabular}

Pada tabel ini tampak untuk variabel data produksi terdapat tonase per hektar dan janjang/pokok sedangkan untuk karakteristik lahan terdapat dataran dan perbukitan. Sementara untuk hasil ratarata dan hasil uji homogenitas dapat dilihat pada tabel 4 berikut ini : 
Tabel 4. Dependent Variabel: Uji Homogenitas

\begin{tabular}{cccc}
\hline$F$ & $d f 1$ & df2 & Sig. \\
\hline 1.691 & 3 & 44 & 0.183 \\
\hline
\end{tabular}

Berdasarkan hasil pengolahan data , diperoleh nilai Sig sebesar 0.183 , oleh karena itu nilai Sig lebih basar dari pada 0.05, maka dapat diketahui hasil uji homogenitas pada tabel di atas bersifat homogen, sehingga asumsi dalam uji two way anova terpenuhi.

Setelah melalui beberapa tahapan uji, akan diketahui hasil penelitian pada two way anova pada hipotesis yang dapat dilihat pada tabel berikut ini :

Tabel 5. Hipotesis Penelitian

\begin{tabular}{lrrrrr}
\hline \multicolumn{1}{c}{ Source } & $\begin{array}{c}\text { Type III Sum } \\
\text { of Squares }\end{array}$ & \multicolumn{1}{c}{ df } & Mean Square & \multicolumn{1}{c}{ F } & \multicolumn{1}{c}{ Sig. } \\
\hline Corrected & $25.565^{\mathrm{a}}$ & 3 & 8.522 & 49.054 & 0.000 \\
Model & 190.125 & 1 & 190.125 & 1094.434 & 0.000 \\
Intercept & 25.535 & 1 & 25.535 & 146.992 & 0.000 \\
Produksi & 0.001 & 1 & 0.001 & 0.006 & 0.937 \\
Karakteristik & 0.029 & 1 & 0.029 & 0.164 & 0.687 \\
Produksi $^{*}$ & & & & & \\
Karakteristik & 7.644 & 44 & 0.174 & & \\
Error & 223.333 & 48 & & & \\
Total & 33.209 & 47 & & & \\
$\quad$ Corrected & & & & & \\
Total & & & & & \\
\hline
\end{tabular}

Dasar pengambilan keputusan dalam uji two way anova, diperoleh nilai Sig sebesar 0.000 lebih kecil dari pada 0.05 sehingga dapat diputuskan ada perbedaan hasil produksi berat dan jumlah janjang terhadap pengaruh karakteristik lahan. Kemudian diperoleh nilai Sig sebesar 0.937 lebih besar dari pada 0.05 sehingga dapat diputuskan bahwa tidak ada pengaruh signifikan terhadap hasil produksi berat dan jumlah janjang pada topografi lahan dan diperoleh nilai Sig sebesar 0.687 lebih besar dari pada 0.05 , maka dapat diputuskan bahwa tidak ada interaksi pada karakteristik lahan datar dengan perbukitan terhadap menentukan hasil produksi.

\section{Pembahasan}

1. Topografi Lahan

Berdasarkan hasil penelitian menunjukan bahwa topografi lahan mempengaruhi adanya perbedaan pada hasil produksi tahun 2019 antara tonase per hektar dengan jumlah janjangan per pokok, namun hasil produksi yang disebabkan oleh topografi lahan tidak berpengaruh signifikan. Kemudian tidak ada interaksi antara karakteristik lahan datar dengan perbukitan terhadap hasil produktivitas kelapa sawit tahun 2019.

2. Hasil Produksi

Dari hasil pengumpulan data produksi kelapa sawit tahun 2019 dapat di lihat pada gambar 1 berikut ini : 


\section{Produksi Ton/Ha 2019}

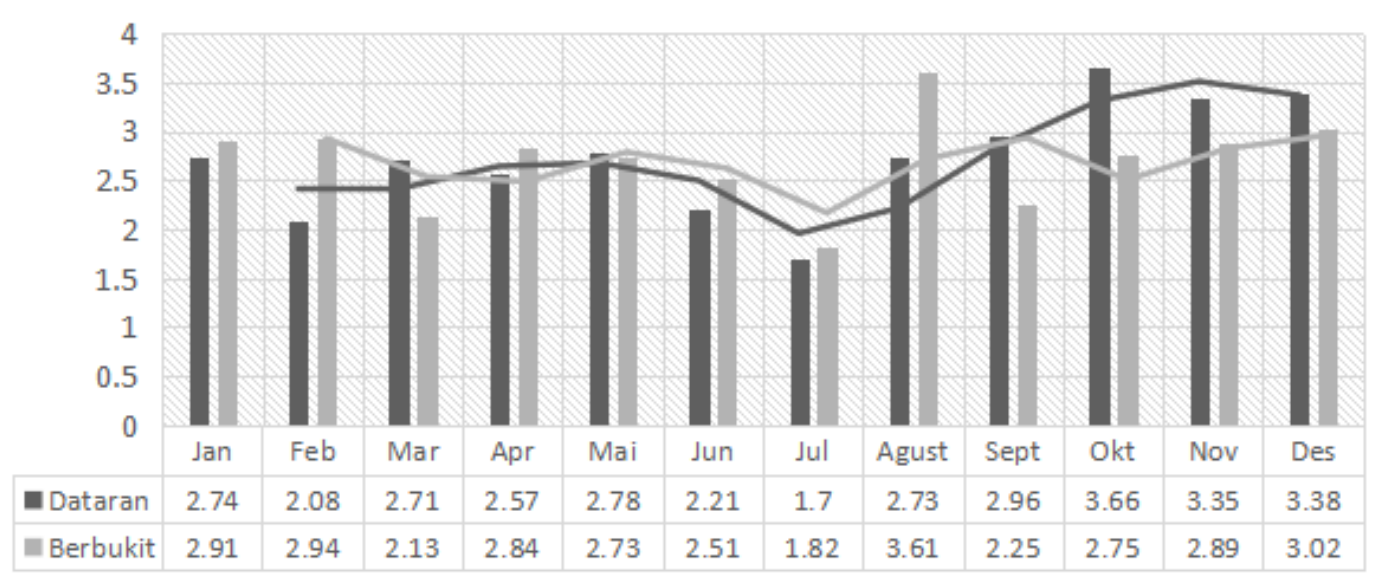

Gambar 1. Grafik rata-rata produksi tonase per hektar tahun 2019

Dari grafik produksi ton/ha di atas dapat dilihat bahwa hasil produksi pada lahan dengan karakteristik dataran, hasil produksi pada bulan Januari sampai dengan bulan Juni berkisar antara 2.08 sampai dengan 2.78 ton/ha, kemudian pada bulan Juli sampai dengan bulan Oktober berangsur naik. Untuk hasil produksi tertinggi pada lahan dengan karakteristik dataran terjadi pada bulan Oktober yakni mencapai 3.66 ton/ha. Sedangkan untuk karakteristik lahan perbukitan dinilai lebih stabil dari bulan Januari sampai dengan bulan Juni berkisar antara 2.13 sampai dengan 2.94 ton/ha. Untuk hasil produksi tertinggi pada lahan dengan karakteristik perbukitan terjadi pada bulan Agustus yakni mencapai 3.61 ton/ha dan kemudian mengalami penurunan hasil produksi pada bulan September menjadi 2.25 ton/ha. Untuk hasil produksi jumlah janjang per pokok tahun 2019 dapat dilihat pada gambar 2 berikut ini :

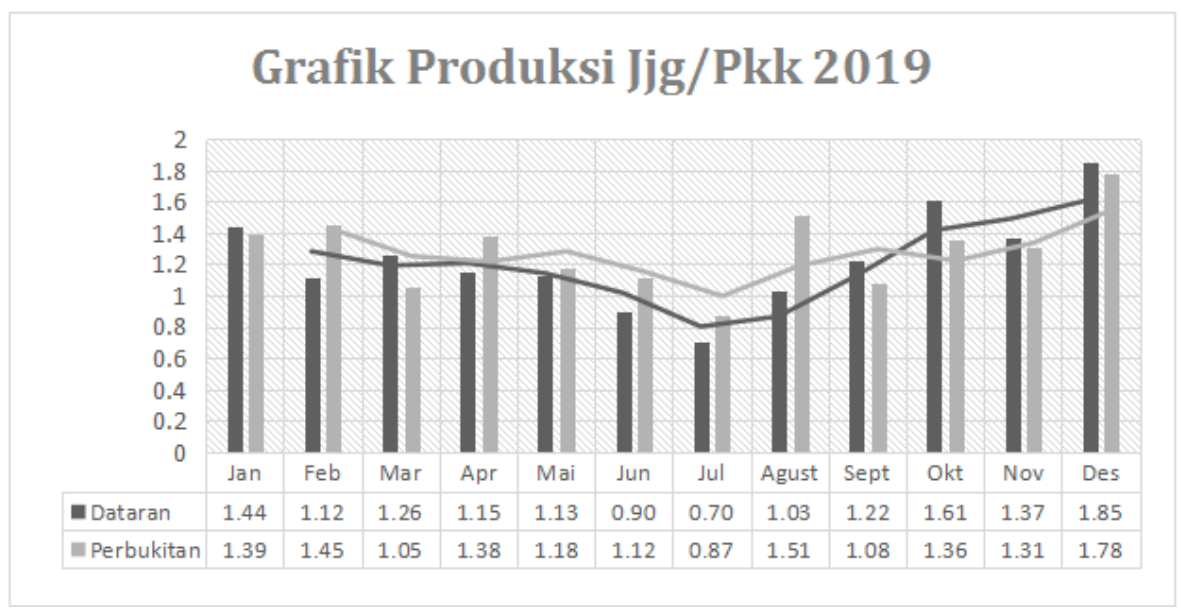

Gambar 2. Grafik rata-rata produksi janjang per pokok tahun 2019 
Dari grafik produksi jjg/pkk di atas dapat dilihat bahwa kedua perlakuan terjadi penurunan produksi dari bulan Januari hingga bulan Juli, kemudian pada karakteristik lahan dataran terjadi kenaikan pada bulan Agustus dan produksi tertinggi terjadi pada bulan Desember yakni mencapai 1.85 jjg/pkk. Sementara itu produksi pada lahan dengan karakteristik perbukitan mengalami ketidakstabilan produksi pada bulan Agustus hingga bulan November, sedangkan untuk hasil produksi tertinggi terjadi pada bulan Desember.

Telah diketahui bahwa ada perbedaan antara berat (ton/ha) dengan jumlah (jjg/pkk) namun topografi yang ada tidak berpengaruh signifikan terhadap hasil produksi keseluruhan serta tidak ada interaksi antara topografi lahan dengan produksi.

Dari hasil analisa data di atas, diasumsikan penyebab dan dipengaruhi oleh beberapa faktor yaitu :

1. Faktor lingkungan

Faktor lingkungan sangat mempengaruhi pertumbuhan dan produksi tanaman (Mcilory 1976). Dari hasil pengamatan, observasi di lapangan dan pengumpulan data dari berbagai pihak yang bersangkutan, penulis meyakini dan dapat diasumsikan penyebab terhadap hasil penelitian ini yakni : a. Intensitas matahari merupakan faktor penting dalam metabolisme tanaman yang mempunyai hijau daun, karena dapat dikatakan bahwa produksi tanaman dipengaruhi oleh ketersediaan sinar matahari. Pengaruh penyinaran matahari yang terjadi pada $\mathrm{P} 1$ dapat dikatakan merata karena kondisi lahan yang benar-benar dataran dibandingkan P2 yang karakteristik lahannya naik dan turun sehingga terdapat persaingan untuk mendapatkan sinar matahari antar pokok tanaman kelapa sawit yang posisinya berada di bawah, yang menyebabkan konsentrasi pertumbuhan lebih ke arah peninggian pokok, oleh karena itu jumlah produksi janjang yang dihasilkan lebih tinggi namun beratnya lebih rendah dibandingkan dengan P1 yang intensitas mataharinya lebih merata. Menurut Parman (2010) intensitas cahaya matahari yang berbeda akan menyebabkan terjadinya perbedaan pada parameter pertumbuhan yang berbeda pula pada tanaman.

b. Curah hujan. Dari hasil pengumpulan data curah hujan pada tahun 2019 dapat dilihat pada tabel berikut :

Tabel 6. Data curah hujan tahun 2019

\begin{tabular}{lcccc}
\hline \multirow{2}{*}{ Bulan } & \multicolumn{2}{c}{$\mathrm{P} 1$} & \multicolumn{2}{c}{$\mathrm{P} 2$} \\
\cline { 2 - 5 } & $\mathrm{CH}(\mathrm{mm})$ & $\mathrm{HH}$ & $\mathrm{CH}(\mathrm{mm})$ & $\mathrm{HH}$ \\
\hline Januari & 34 & 2 & 6 & 2 \\
Februari & 70 & 2 & 103 & 4 \\
Maret & 194 & 13 & 233 & 12 \\
April & 199 & 15 & 302 & 16 \\
Mei & 252 & 14 & 358 & 15 \\
Juni & 139 & 7 & 70 & 6 \\
Juli & 93 & 6 & 59 & 6 \\
Agustus & 62 & 4 & 12 & 4 \\
September & 33 & 5 & 25 & 5 \\
\hline
\end{tabular}




\begin{tabular}{ccccc}
\hline \multirow{2}{*}{ Bulan } & \multicolumn{2}{c}{$\mathrm{P} 1$} & \multicolumn{2}{c}{$\mathrm{P} 2$} \\
\cline { 2 - 5 } & $\mathrm{CH}(\mathrm{mm})$ & $\mathrm{HH}$ & $\mathrm{CH}(\mathrm{mm})$ & $\mathrm{HH}$ \\
\hline Oktober & 138 & 11 & 62 & 9 \\
November & 159 & 9 & 174 & 10 \\
Desember & 120 & 10 & 120 & 10 \\
\hline Rata-rata & 124 & 8 & 127 & 8 \\
\hline Total 2019 & 1493 & 98 & 1524 & 99 \\
\hline
\end{tabular}

Keterangan:

$\mathrm{CH}=$ Curah hujan

$\mathrm{HH}=$ Hari hujan

Dari tabel data curah hujan di atas dapat kita lihat bahwa curah hujan pada kedua perlakuan baik P1 maupun P2 tidak ada perbedaan yang signifikan, melihat total curah hujan $(\mathrm{CH})$ pada perlakuan P1 sebesar $1493 \mathrm{~mm}$ dengan rata-rata $124 \mathrm{~mm}$ kemudian total hari hujan $(\mathrm{HH})$ sebanyak 98 hari, dan pada perlakuan P2 total curah hujan $(\mathrm{CH})$ sebesar $1524 \mathrm{~mm}$ dengan rata-rata $127 \mathrm{~mm}$ kemudian total hari hujan $(\mathrm{HH})$ sebanyak 99 hari, hal ini menandakan bahwa hujan yang terjadi merata, sehingga tidak menyebabkan perbedaan jumlah produktivitas kelapa sawit yang signifikan. Menurut Hartanto (2011) tanaman kelapa sawit menghendaki curah hujan 1.500-4.000 mm per tahun, tetapi curah hujan optimal adalah 2.000-3.000 mm per tahun, dengan jumlah hari hujan tidak lebih dari 180 hari per tahun.

c. Drainase. Pada perlakuan P1 dengan lahan yang datar berpotensi mendapatkan hasil produksi yang maksimal, hanya saja pada drainase yang ada di lokasi perlakuan $\mathrm{P} 1$ dengan lahan yang datar tidak berfungsi normal, sehingga pada saat intensitas hujan yang tinggi, lokasi tersebut riskan terjadinya genangan air yang disebabkan meluapnya aliran drainase yang tidak dapat menampung debit air yang besar, hal ini berimbas pada pemupukan yang telah diberikan, hanyut terbawa oleh arus air. Menurut Triadi (2002), drainase adalah suatu usaha untuk menyalurkan dan mengeringkan sejumlah kelebihan air dari suatu wilayah ke wilayah lain, sehingga didapat suatu lingkungan yang kering di wilayah tersebut.

d. Kesuburan lahan. Kesuburan tanah adalah kemampuan atau kualitas suatu tanah menyediakan unsur hara tanaman dalam jumlah yang mencukupi kebutuhan tanaman, dalam bentuk senyawasenyawa yang dapat dimanfaatkan tanaman dan dalam perimbangan yang sesuai untuk pertumbuhan tanaman tertentu dengan didukung oleh faktor pertumbuhan lainnya (Rosmarkam dan Yuwono, 2002).

2. Faktor perlakuan

Untuk mendapatkan hasil produksi yang maksimal maka diberikan perlakuan dengan optimal. Ada beberapa perlakuan yang diberikan pada tanaman kelapa sawit yang ada pada lokasi penelitian yakni :

a. Pemupukan

Menurut Farasati (2018) pemupukan merupakan upaya penambahan unsur hara esensial dari luar, baik dalam bentuk kimia dan organik. Pemupukan yang diberikan pada pokok sawit yang ada pada lokasi penelitian terbagi menjadi 2 jenis yakni : 
1) Pengaplikasian pupuk kimia yang mengandung unsur Nitrogen, Kalium, Phosfor, Boron dan juga Magnesium.

2) Land Application atau aplikasi tanah berupa pemanfaatan limbah hasil pengolahan pabrik kelapa sawit (PKS) seperti janjang kosong dan limbah cair yang diasumsikan dapat menyuburkan dan memberikan nutrisi tambahan pada tanaman kelapa sawit dengan unsurunsur yang terkandung adalah Nitrogen, Kalium dan Phosfor.

Pengaplikasian di atas, diberikan secara merata pada setiap tanaman, dengan dosis yang telah direkomendasikan oleh tim riset dari perusahaan sesuai dengan kebutuhan tanaman. Pada land application yang diberikan kepaada perlakuan P1 berupa janjang kosong, sementara pada perlakuan P2 sebagian besar disalurkan limbah cair pada flatbed dan sebagiannya lagi diaplikasikan janjang kosong. Terkhusus pada perlakuan P1 pengaplikasian pupuk kimia dilakukan secara mekanis berlawanan dengan perlakuan P2 yang dilakukan secara manual. Hal ini berkaitan pada bagian drainase sebagaimana yang telah dijelaskan sebelumnya. Maka dari itu produktivitas yang dihasilkan tidak signifikan.

b. Konservasi

Perlakuan konservasi yang diberikan dalam hal ini adalah terasering yang sebagian besar diaplikasikan pada perlakuan P2 yang memiliki karakteristik kelerengan $>30$ derajat. Terasering sendiri dalam konsep awal untuk menjaga dan meningkatkan kestabilan lereng, memperbanyak resapan air, mengurangi run off atau kecepatan aliran air yang akan menyebabkan erosi pada kelerengan. Hal ini juga berperan sebagai pendukung peningkatan hasil produksi. Menurut Arsyad (2006), konservasi tanah adalah suatu upaya penggunaan tanah yang terdapat di permukaan bumi untuk keperluan atau kebutuhan manusia secara efisien dan memenuhi kebutuhan lingkungan.

3. Faktor genetik

Gen merupakan substansi pembawa sifat yang diturunkan dari induk ke generasi selanjutnya. Gen mempengaruhi ciri dan sifat makhluk hidup dimana pada tanaman mempengaruhi bentuk tubuh, hasil produksi dan lain-lain yang berkaitan dengan genetik. Berikut adalah tabel produsen pemuliaan tanaman kelapa sawit.

Tabel 7. Produsen penyedia bibit

\begin{tabular}{|c|c|c|c|}
\hline Produsen bibit & $\mathrm{P} 1$ & $\mathrm{P} 2$ & Total \\
\hline Socfindo & 13 & 17 & 30 \\
\hline Lonsum & 7 & 1 & 8 \\
\hline Total & 20 & 18 & 38 \\
\hline
\end{tabular}

Pada tabel di atas dapat dilihat bahwa bibit yang ditanam merupakan bibit bersertifikat, namun dari 2 perusahaan yang berbeda. Hal ini 
diduga menjadi penyebab jumlah produksi tonase per hektar dan janjang per pokok ada perbedaan namun tidak signifikan. Gen merupakan substansi pembawa sifat yang diturunkan dari induk ke generasi selanjutnya. Gen mempengaruhi ciri dan sifat makhluk hidup dimana pada tanaman mempengaruhi bentuk tubuh, warna bunga, dan rasa buah. Gen juga menentukan kemampuan metabolisme sehingga sangat mempengaruhi pertumbuhan dan perkembangan tanaman tersebut (Anonim, 2017).

\section{KESIMPULAN}

Dari penelitian ini dapat disimpulkan bahwa pengaruh karakteristik lahan menyebabkan adanya perbedaan hasil produksi bobot (ton/ha) dengan jumlah (jjg/pkk) namun tidak signifikan terhadap hasil produksi keduanya serta tidak ada interaksi antara pengaruh karakterisik lahan sesuai dengan yang telah diklasifikasikan. Hal ini dapat terjadi diduga berkaitan erat dengan lingkungan tumbuh, perlakuan yang diberikan kemudian sifat genetik yang ada pada tanaman kelapa sawit.

Perlu adanya penelitian lanjutan untuk merekomendasikan kepada perusahaan atau pengusahawan yang bergerak di bidang perkebunan kelapa sawit untuk mempertimbangkan karakteristik lahan, agar mempermudah pelaku usaha untuk mendapatkan hasil produksi tinggi, sebab lahan dengan klasifikasi datar mendapat nilai tambah dibandingkan dengan lahan lereng, hal ini dilihat pada proses pertumbuhan tanaman kelapa sawit yang lebih ideal dan rata dari segi ketinggian pokok dan diameter pokok. Untuk selanjutnya diperlukan riset lebih lanjut dan mendalam pada karakteristik lahan guna mengoptimalkan lahan yang ada.

\section{DAFTAR PUSTAKA}

Anonim. (2014). Sekilas Kalimantan Timur. Diakses pada tanggal 15 Agustus 2019, dari: https://kaltimprov.go.id/halaman/kon disi-wilayah

Anonim. (2017). Faktor-faktor yang Mempengaruhi Pertumbuhan dan Perkembangan Tanaman. Diakses pada tanggal 22 September 2020, dari:

https://www.pioneer.com/web/site/in donesia/Faktor-Faktor-yang-

Mempengaruhi-Pertumbuhan-dan-

Perkembangan-Tanaman

Arsyad, S. (2006). Konservasi Tanah dan Air. Bogor (ID): IPB Press.

Farasati, R. (2018). Pemupukan Berimbang Kunci Menjaga Kesuburan Tanah. Diakses pada tanggal 22 September 2020, dari: https://agrodite.com/wpcontent/uploads/2018/11/Pemupuka n-berimbang-kunci-menjagakesuburan-tanah

Handoko. (1995). Klimatologi Dasar: Landasan Pemahaman Fisika Atmosfer dan Unsur-Unsur Iklim. Bogor (ID): IPB Press.

Hartanto. (2011), Sukses Besar Budidaya Kelapa Sawit. Yogyakarta: Penerbit Citra Media Publishing.

Kartasapoetra, A. G. (1990). Kerusakan Tanah Pertanian dan Usaha Untuk Merehabilitasinya. Jakarta: Bina Aksara.

Kartasapoetra, A. G., dan M. M. Sutedjo. (1987). Teknologi Konservasi Tanah dan Air. Jakarta: Bina Aksara.

Triadi, L. Budi. (2002). Pengelolaan Sistim Tata Air Lahan Rendah. Prosiding Peringatan Hari Air Sedunia 2002 dan Forum Air Indonesia II, Pekanbaru.

Martono. (2004). Pengaruh Intensitas Hujan dan Kemiringan Lereng Terhadap Laju Kehilangan Tanah 
Pada Tanah Regosol Kelabu. Tesis. Universitas Diponegoro, Semarang.

Mcilory, R. J. (1976). Pengantar Budidaya Padang Rumput Tropika. Jakarta: Pradnya Paramita.

Parman, (2010). Pengaruh Intensitas Cahaya Terhadap Produksi Umbi Tanaman Lobak (Raphanus sativus L). Jurnal Buletin Anatomi dan Fisiologi, 18 (2) : 29

Rosmarkam A, dan Yuwono N.W. (2002). Ilmu Kesuburan Tanah. Yogyakarta: Kanisius.

Sangadji, S. (2001). Pengaruh Iklim Tropis di Dua Ketinggian Tempat yang Berbeda Terhadap Potensi Hasil Tanaman Soba (Fagopyrum esculentum Moench.). Tesis. IPB, Bogor. 